Amer. J. Bot. 63(4): 481-491. 1976.

\title{
DEVELOPMENT AND DISTRIBUTION OF MUCILAGE CANALS IN LYCOPODIUM ${ }^{1}$
}

\author{
JAMES G. BRUCE \\ Department of Botany, University of Michigan, Ann Arbor, Michigan 48109
}

A B S T R A C T

Two distinct types of mucilage canals are found in Lycopodium. One type, the veinal canal, is found in both sporophylls and in vegetative leaves, and is always in close proximity to the leaf trace. The other, the basal canal, is restricted to the strobilus where it forms a complex and extensive mucilaginous cylinder in the outer cortex and extends into the base of the sporophylls. Protruding secretory cells are formed in both types during a lysigenous developmental process. The occurrence of these two types of canals correlates with the three subgenera. Urostachys which lacks canals, Lepidotis which possesses both veinal and basal canals, and Lycopodium which possesses only basal canals.

MuCILAGE CANALS or cavities have been known in the Lycopodiaceae since Hegelmaier (1872) first noted their presence in three species, $L y$ copodium inundatum, $L$. alopecuroides, and $L$. annotinum. He followed development of the canals only in the rhizome of $L$. inundatum and concluded that it was basically schizogenous. Hill (1906) described development of mucilage canals in the sporophylls of L. clavatum. He discovered a process of lysigenous degeneration which spread from the sporophyll down the cortex almost to the insertion of the next leaf. Unfortunately, Hill did not compare his findings to those of Hegelmaier.

Glück (1895) demonstrated two different canals associated with each sporophyll in the strobilius of $L$. inundatum. One was restricted to the distal spreading portion of the sporophyll and the other occurred in the base. Furthermore, Gliick showed this basal canal to be confluent with adjacent canals of neighboring sporophylls, thereby forming a continuous mucilage cavity throughout the strobilus. The relationship of these two canals to those in L. annotinum (Hegelmaier, 1872) was not discussed. Also, Hill (1906) did not compare the situation in $L$. clavatum to Glück's study of $L$. inundatum.

With the exception of Glück's paper (1895), the occurrence of two canal types is not mentioned in the literature. In a short note on the sporophyll of $L$. inundatum, Sykes (1909) illustrated a transection of a sporophyll wherein both

${ }^{1}$ Received for publication 27 March 1975.

I thank Ms. Joyce Bergan for assistance in preparation of the pen and ink illustration, Dr. David W. Bierhorst for preserved materials of Lycopodium drummondii, Dr. Donald J. Drapalik for his kind help in supplying materials of $L$. cernuum, Dr. David B. Lellinger for the loan of materials of $L$. cruentum, and Drs. Warren $\mathrm{H}$. Wagner, $\mathbf{J}_{\mathbf{r}}$, and Michael $\mathbf{R}$. Mesler for their encouragement, advice, and critical review of the manuscript. canals may be seen. However, the feature was not discussed.

Subsequent research on mucilage canals mainly documented their occurrence in various taxa (Bhambie, 1965; Bierhorst, 1971; Bower, 1894; Chu, 1974; Eiger, 1956; Jones, 1905; Lloyd and Underwood, 1900; Smith, 1955; Sykes, 1908). The canals were described for all three subgenera, Urostachys, Lepidotis, and Lycopodium (nomenclature after Wilce, 1972). The presence of mucilage canals in subgenus Urostachys, however, is in doubt. Whereas Sykes (1908) reported mucilage canals in five species ( $L$. lucidulum, $L$. selago, L. serratum, L. squarrosum, and L. tetragonum), earlier work by Jones (1905) and later by Bhambie (1965) had shown no mucilage passages in four of these, $L$. selago, $L$. serratum, $L$. squarrosum, and L. tetragonum. Jones reported air cavities in the stems of $L$. selago, but he saw no evidence of mucilage canals.

Several issues are, therefore, left unresolved concerning both development and distribution of the canals. For example, it is unclear whether the canals of vegetative leaves and those of sporophylls are comparable. Also, there are contradictions regarding the distribution of the canals and the differences between canals and air cavities. In view of these considerations, the objectives of the present investigation are (1) to provide a comparative developmental study of the canals of both vegetative leaves and sporophylls so that an assessment of their homologies can be made, and (2) to survey the distribution of the canals in vegetative leaves and sporophylls in order to determine the taxonomic value of the character.

Materials AND METHODS-Stem apices, stem segments (rhizomes, upright branches, and peduncles), and strobili were fixed in either FAA, FPA (Johansen, 1940), CRAF III, or CRAF IV 


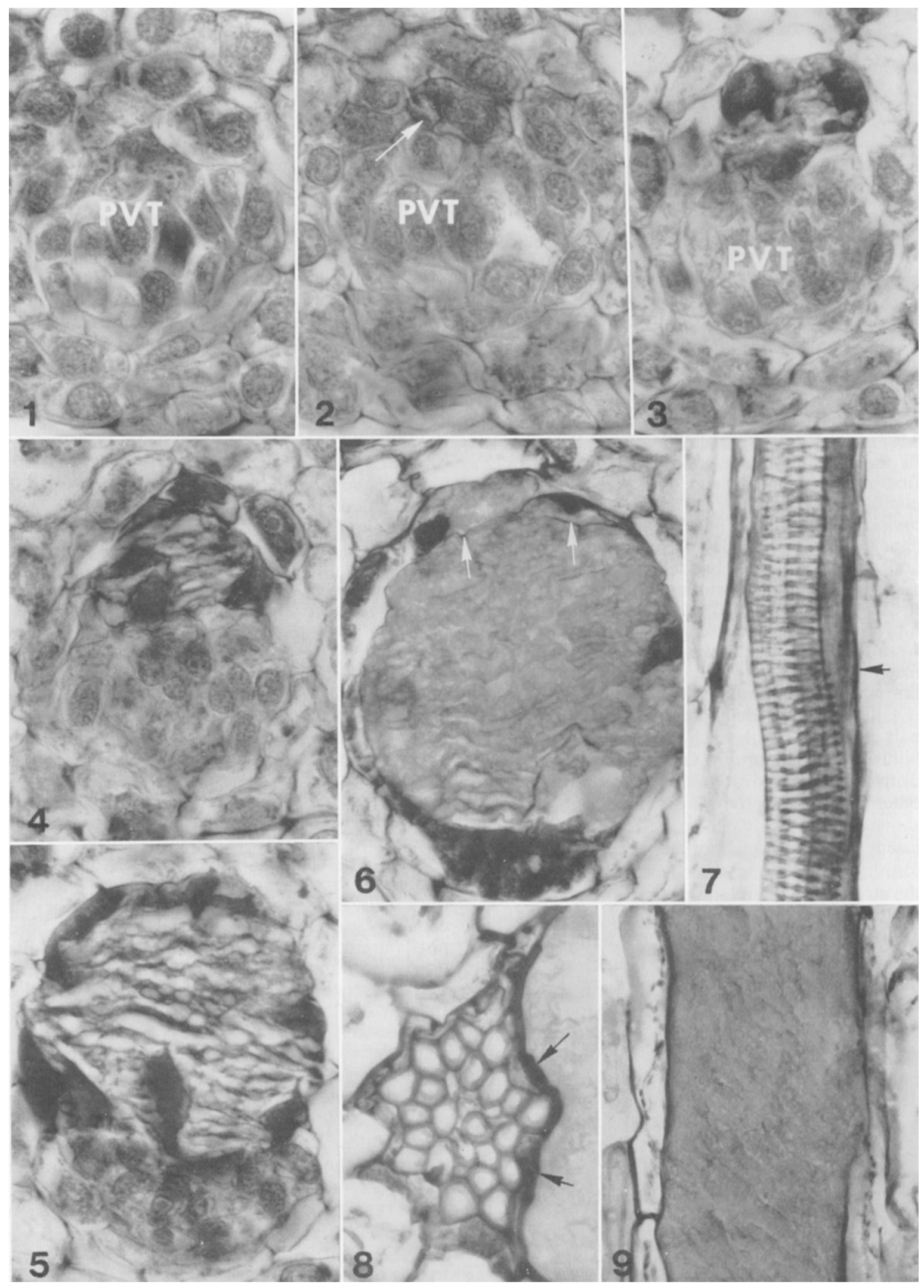


(Sass, 1958). They were dehydrated in tertiary butyl alcohol, embedded in Paraplast tissue embedding medium, and sectioned at thicknesses from $6-14 \mu \mathrm{m}$. Thirty-two stem apices, 66 stem segments, and 36 strobili were studied by this method. In addition, material was rehydrated from herbarium specimens in a dilute $\mathrm{NaOH}$ solution (Schmid, 1971) and prepared for microtoming as above. Twenty-three strobili and two stem segments were examined in this way. Materials were stained either in safranin-fast green (Johansen, 1940) or by Sharman's (1943) safranin, orange- $G$, tannic acid, and iron alum technique. Additionally, living materials were hand-sectioned to verify presence and nature of gross canal features. Photomicrographs were made on Panatomic-X film using a Zeiss Standard WL research microscope. Additional photographs were made on Tri-X and Ektapan sheet film with an Aristophot $4 \times 5$ view camera.

OBSERVATIONS-Two types of mucilage canals exist in Lycopodium. One type is invariably associated with the leaf trace and is found in both vegetative leaves and sporophylls. The other is found only in the strobilus. First I shall describe the canals in the vegetative leaves and then those in the strobilus where the organization is more complex.

The canal in the vegetative leaf is tubular and extends from the outer cortex, where it is broadest, up into the leaf where it narrows and terminates near the tip. It is bounded by parenchyma cells (Fig. 9) except in the region of the leaf vein. Within the outer cortex the canal diverges from the vein and remains within the outer cortical region. In $L$, alopecuroides, with its conspicuous air cavities, the canal in the outer cortex is bounded by a prominent single layer of cells (Fig. 18). In the other species with canals in the vegetative leaves, this layer is much less distinctive. The canal is separated from the abaxial side of the leaf trace by a single layer of cells except near its lower end in the outer cortex (Fig. 7, 8). This layer of cells is quite thin in diameter. Chu (1974) states that this separating layer was often entirely absent. However, I found no evidence to support his conclusion. In all cases observed, cells could be seen between the tracheids and the mucilage canal. This vein-associated canal, or veinal canal, occurs in rhizome, peduncle, and strobilus.

The sporophyll in many species of Lycopodium consists of a distal upright or spreading portion which is exposed externally, and a proximal stalklike portion to which the sporangium is attached (Fig. 22, 27). A veinal canal may or may not be present within the sporophyll (Fig. 27). A second type of canal is found in the basal, proximal portion of the sporophyll. This canal, termed basal canal, occupies the entire proximal portion of the sporophyll and is bounded externally by the epidermis (Fig. 16). It is separated from the vein by several cell layers or by the veinal canal when it is present (Fig. 15, 17). In the proximal portion of a sporophyll when a basal and veinal canal are both present, a single layer of cells separates them (Fig. 15). In the outer cortex of the strobilus the basal canals are flared and form a sheath just beneath the epidermis (Fig. 23). This mucilage cylinder is perforated at regular intervals by the sporophyll traces (Fig. 26). In the mature strobilus all basal canals are confluent within the outer cortex (Fig. 23, 26).

Veinal canal development in the vegetative shoot-Development of the veinal canal begins either immediately adjacent to the provascular tissue of the leaf vein or actually in the peripheral cells of the provascular tissue. At this stage in the development of the leaf it is very difficult to define the boundary between provascular tissue and the meristematic cells in regions outside the provascular tissue (Fig. 1). The canal can first be observed along the abaxial side of the provascular tissue column in the region of the leaf very close to the point of insertion on the stem (Fig. 2). From this point it spreads both proximally into the outer cortex and distally toward the leaf tip. Figures 1-6 present a sequence at the same level in a series of leaves from one apex.

Initially, the protoplast of a single cell along the abaxial side of the provascular tissue begins to contract, its plasmalemma separating from its cell walls (Fig. 2). Simultaneously, the bounding wall of this cell is apparently dissolving. Figures 6,13 (arrows) show this process occurring where the walls of cells undergoing this contraction are partially disintegrated. With contraction of the protoplast, this initial contracting cell begins to stain densely and mucilage can be seen peripherally occupying the space formally filled by the fully expanded protoplast. At this point the canal consists of a contracted, plasmalemma-bound protoplast surrounded by mucilage. The bounding wall of the canal consists of the cell walls of

$\leftarrow$

Fig. 1-9. Development of veinal canal in Lycopodium alopecuroides. 1-5. Transections at same relative level in leaves from one rhizome apex. Fig. 2 shows first evidence of canal formation (arrow). $\times 845$. 6 . Older veinal canal in transection. Lysigenous disintegration of walls of cells bordering lumen (arrows). $\times 625$. 7 . Longisection of veinal canal in leaf illustrates cells separating vein from veinal canal (arrow). $\times 530$. 8. Veinal canal in transection shows cells which separate vein from veinal canal (arrows). $\times 725$. 9. Longisection in plane of leaf. Canal bordered by ordinary leaf parenchyma. $\times 310$. PVT, provascular tissue. 


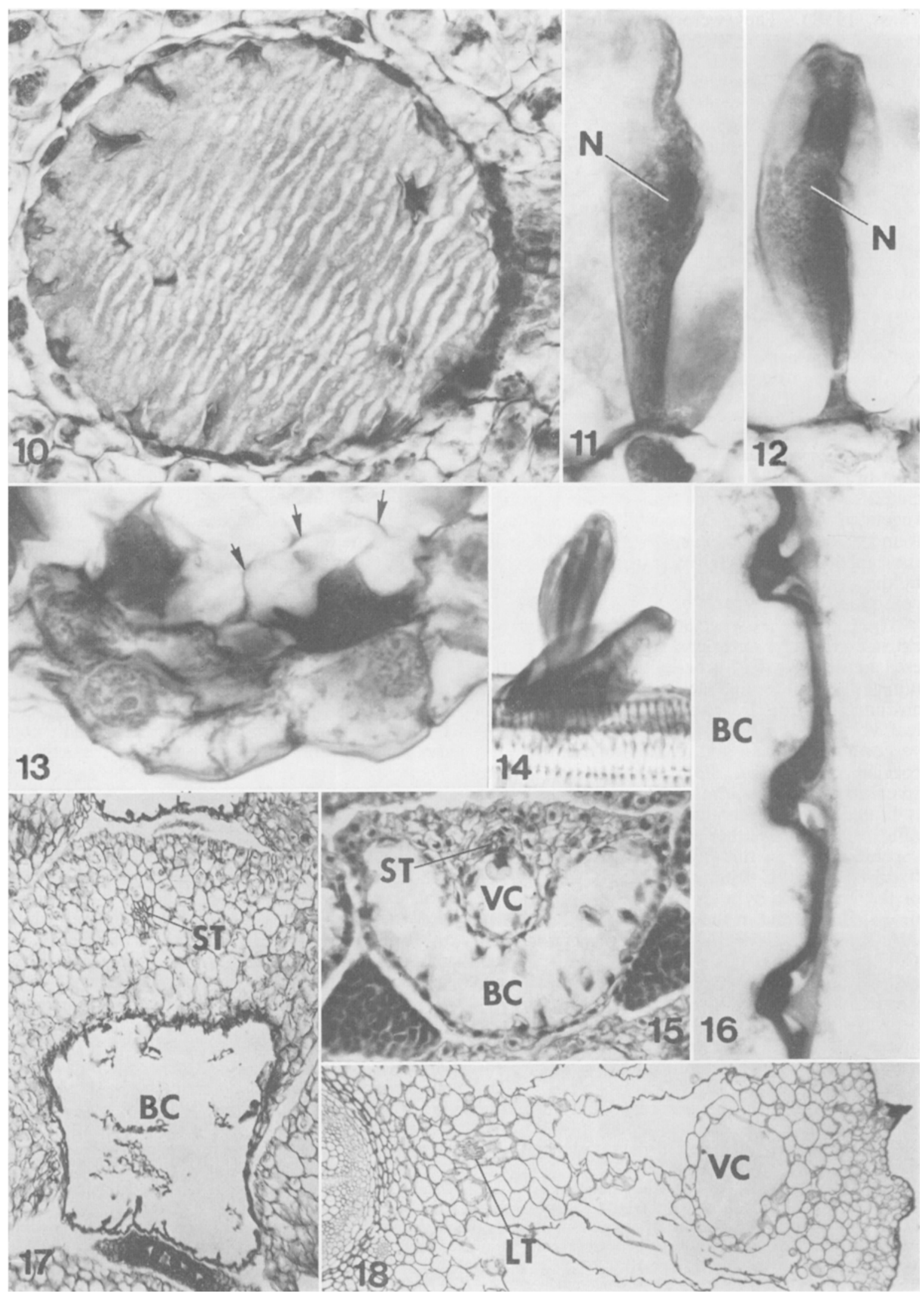


adjacent cells because the original wall of the now contracted cell has dissolved. Repetition of this process in cells adjacent to the canal enlarges the canal. These contracted protoplasts are termed protruding cells. The protruding cells assume various forms and may, in more developed canals, become elongated (Fig. 11, 12). They are quite varied in transection, showing irregular or starshaped patterns which gives these cells a high surface area to volume ratio and supports a secretory function (Fig. 10).

The protruding cells appear to be naked protoplasts because in numerous observations (1) no evidence of a cell wall could be seen, only the thin bounding line marking the protoplast, (2) the cells had various configurations suggesting a very plastic exterior (Fig. 10), and (3) in rare instances these cells could be seen within partially disintegrated cell walls (Fig. 6, 13).

As the canal enlarges, these naked protoplasts are highly distended and protrude into the lumen of the canal (Fig. 11, 12,14). The nature of the point of attachment of these cells to adjacent cells is unclear. These cells may be oriented variously with respect to the axis of the canal, but they generally extend perpendicularly from the wall of the canal. The cells are nucleate and they possess a conspicuous dark-staining cytoplasm (Fig. 11, 12). Nucleoli are often seen within the nuclei.

At the time of its inception $500-600 \mu \mathrm{m}$ below the stem apex, the canal is approximately three cell layers from the abaxial surface of the leaf. At maturity the canal, although now greatly enlarged, is still approximately three cell layers from the abaxial surface. At the same time the canal has remained in intimate association with the provascular tissue and eventually with the vascular tissue of the leaf. Also, at its inception there are three or four cells which border the cavity (as seen in transection) near insertion of the leaf on the axis (Fig. 2), but by the time of canal maturity there are as many as 20 cells bordering the canal (Fig. 10, 18). During development, the lumen of the veinal canal near the provascular tissue is often lined with numerous elongate cells which are thin in transection; these eventually form protruding cells. Only the provascular tissue is obviously meristematic during the later phases of development. This tissue possesses two meristematic flanks that cup the adaxial side of the canal (in transectional view) as a darkly staining band of cells (Fig. 10). These meristematic flanks generate cells which serve as a source of protruding cells. As the canal matures this source becomes increasingly important because the remainder of the lumen margin stabilizes and few additional protruding cells originate from it. Thus, as the leaf expands due primarily to cell enlargement, new protruding cells as well as new marginal cells are added to the canal periphery as a result of meristematic activity only along the adaxial portion of the canal where the provascular tissue and its meristematic flanks contact the canal.

Apparently, individual protruding cells function only briefly and then disintegrate. Best evidence for this is seen in the development of the basal canal. However, when the veinal canal is mature no protruding cells can be observed within the canal.

The growth and development of the veinal canal involves several correlated events. These major contributing processes are (1) repeated formation of protruding cells from both the border cells of the canal as well as the provascular tissue, (2) expansion and maturation of the leaf, (3) meristematic activity in the provascular tissue and its flanks, and (4) eventual dissolution and loss of all protruding cells.

Veinal canal development in the strobilusThe veinal canal in the strobilus arises by processes essentially similar to the foregoing. The differences are quantitative, and they vary with the taxon being studied. In the lower proximal portion of the sporophyll the mature veinal canal lies immediately adjacent to the basal canal. They are separated by only a single cell layer (Fig. 15). Some evidence suggests that this layer may occasionally break down (Fig. 23); however, this disintegration may only be an artifact since it does not occur uniformly. In the strobilus the veinal canal does not extend into the cortex of the axis. It may approach the region of sporangial insertion, as in L. alopecuroides, L. inundatum, L. appressum, and $L$. prostratum; or it may simply be confined to the upright portion of the sporophyll,

$\leftarrow$

Fig. 10-18. Veinal and basal canal development in Lycopodium. 10. Veinal canal in cortex of $L$. alopecuroides. Star-shaped protruding secretory cells can be seen in lumen and along margin. Provascular tissue is to the right. Lines in mucilage are microtoming artifacts. $\times 410$. 11. Basal canal protruding secretory cell in $L$. appressum. $\times 975$. 12. Veinal canal protruding secretory cell in $L$. appressum. $\times 975$. 13 . Basal canal cells undergoing lysigenous wall disintegration (arrows) in $L$. appressum. Protoplasts are contracted. $\times 1250$. 14. Veinal canal, protruding secretory cells along vein in nearly mature canal of $L$. alopecuroides. $\times 490$. 15. Transection through proximal portion of sporophyll of $L$. appressum which shows relative position of basal canal, veinal canal, and sporophyll trace. $\times 245$. 16. Epidermal layer of basal canal in L. prostratum. $\times 850$. 17. Immature basal canal in L. carolinianum which shows wide displacement of canal from vein. $\times 55$. 18 . Veinal canal in cortex of $L$. alopecuroides. $\times 60$. $B C$, basal canal; $V C$, veinal canal; $S T$, sporophyll trace; $L T$, vegetative leaf trace; $N$, nucleus. 


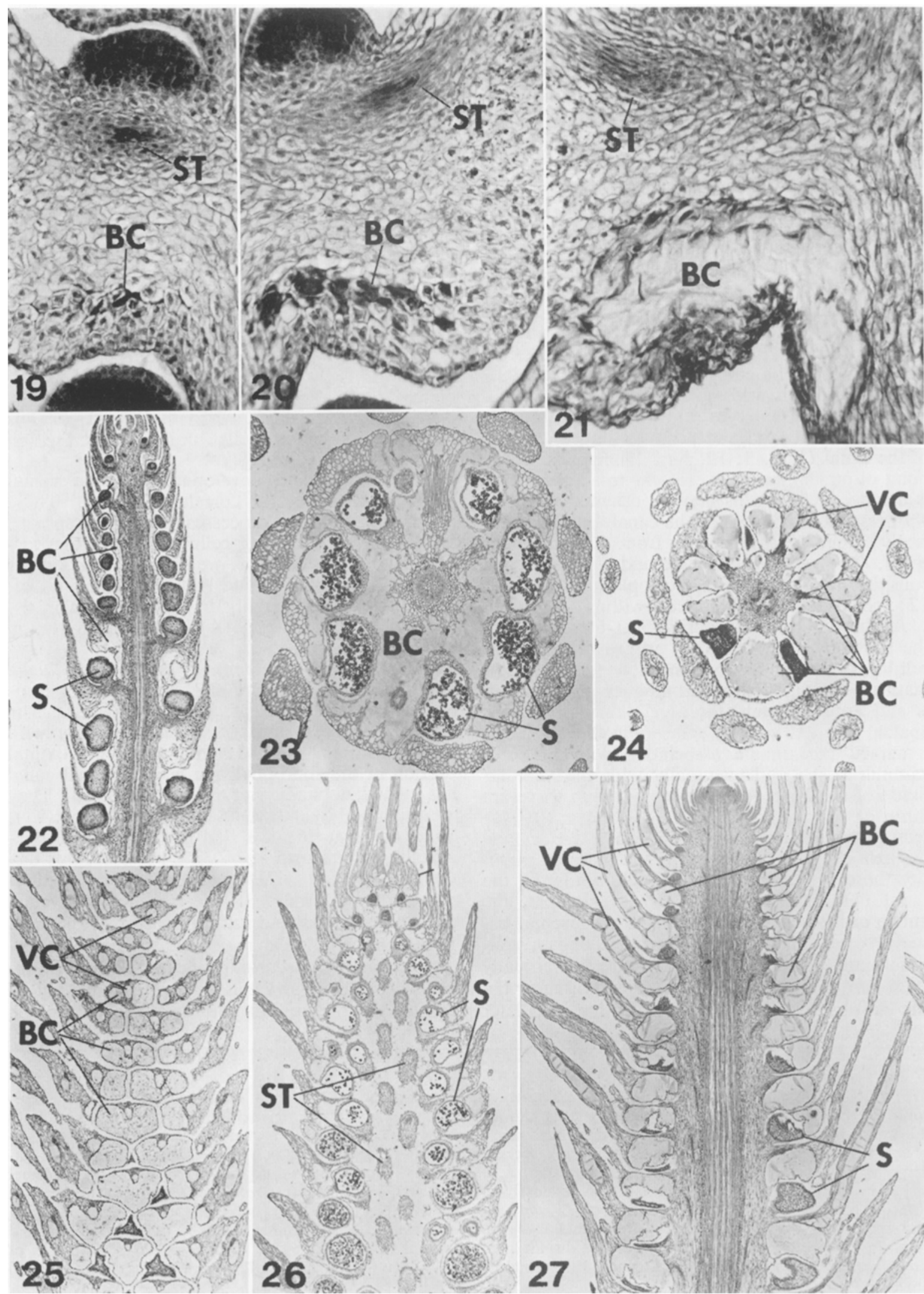


as in L. laterale. Figure 32 is a reconstruction of part of a strobilus in the Lepidotis group. Both veinal and basal canals are apparent, and their spatial relationships are evident.

Basal canal development-The basal canal is first apparent in the sporophyll near its insertion on the strobilar axis (Fig. 19). The canal can first be seen in the strobilus anywhere from 150 $\mu \mathrm{m}$ to $1200 \mu \mathrm{m}$ below the apex. This variation depends not only on the taxon being studied, but also on the age of the strobilus. With maturation of the strobilus, basal canals can be found much closer to the apex. The basal canal, in contrast to the veinal canal, is well below the vein and separated from it by several cell layers (Fig. 17). From this point, development of the basal canal spreads both distally out into the lower portion of the sporophyll and proximally into the outer cortex of the strobilar axis (Fig. 19-22). In the sporophyll base the canal expands to fill the greater portion of this organ (Fig. 25-27). In the mature sporophyll, the basal canal occupies the entire lower portion except for a thin, one cell thick epidermal skin (Fig. 16) and the vein with a small amount of associated parenchyma (Fig. 26). In the cortex the canal expands into the outer 2-4 cell layers. An epidermal cell layer separates the cortical regions of this canal from the exterior (Fig. 23). No thin elongate cells line the lumen, nor is there any residual source of cells from a meristematic region, such as the provascular tissue for the veinal canals. Once canal formation begins, occasional cell divisions occur in adjacent regions of the sporophylls and cortex. However, this meristematic activity ends before canal development is complete. Initially, adjacent basal canals are separated from each other (Fig. 24). With maturation, however, the separating layers dissolve and the canals become continuous throughout the strobilus (Fig. 23, 26).

The protruding secretory cells in basal canals are similar to those of the veinal canals (Fig. 11, 12). However, the secretory cells which occur in species possessing only the basal type of canal often form and later disintegrate without actually protruding into the lumen. Any one secretory cell apparently functions for only a brief period. Formation of the canal depends on the transformation of parenchyma cells into secretory cells.
Subsequent enlargement of the canal then depends on two principal factors, (1) additional transformation of cells neighboring those that are already secretory, and (2) growth and enlargement of the strobilus. This suggests that the points of attachment for secretory cells could dissolve. However, large numbers of free-floating secretory cells are not present in the developing canals. Many of those that in any one section appear to be floating are usually discovered connected to some point along the canal wall in other sections (Fig. 10). An illusion of free-floating may thus result from examination of a single section. The lack of free-floating cells suggests, therefore, that any one secretory cell functions briefly and is then itself dissolved into the canal material. This process yields a mature canal with a homogeneous appearance where no evidence of its formative processes can be found (Fig. 18, 23, 26).

Discussion-Within the extant Lycopodiophyta there are few other examples of mucilage canals or cavities. Most notably, Isoetes histrix (Hill, 1906) has a lysigenous double strand restricted to the sporophyll. Hill also examined several species of Selaginella and found none, and the same was true of Phylloglossum. The phylogenetic and ecological significance of the occurrence of mucilage canals in Isoetes in relation to their similar occurrence in Lycopodium is unclear.

The absence of canals in Phylloglossum is surprising because of the postulated relationship to L. cernuum (subgenus Lepidotis) which possesses both types of canals (Table 1; Bower, 1885; Treub, 1890; Sampson, 1916; Holloway, 1935). More recently Breckon and Falk (1974), on the basis of spore characters, stated that Phylloglossum may be more closely related to subgenus Urostachys, and the absence of mucilage canals in the two taxa supports this. However, it should be noted that Phylloglossum possesses several other features that suggest a relationship with subgenus Lepidotis including habit and habitat similar to many members of subgenus Lepidotis, a strongly differentiated strobilus, an annual tuber similar to structures in $L$. cernuum (but see Sampson, 1916), a superficial green gametophyte, and lack of multicellular paraphyses on the gametophyte (Rothmaler, 1944, 1954).

Also, very young sporophytes of $L$. inundatum

$\leftarrow$

Fig. 19-27. Veinal and basal canals in strobili of Lycopodium. 19-21. Longisections at same relative positions in sporophylls of $L$. dendroideum which show progressive development of basal canal. $\times 125$. 22 . Longisection of strobilus of $L$. sitchense. Vertical confluence of basal canals can be seen in central region. $\times 10.23$. Transection of strobilus of $L$. alopecuroides which shows massive cortical development of mucilage. $\times 15$. 24 . Transection of young strobilus of $L$. intundatum which illustrates both basal and veinal canals. Basal canals are not confluent at this stage. $\times 15$. 25. Tangential longisection of immature strobilus in L. prostratum which transects sporophylls. $\times 10$. 26. Tangential longisection of mature strobilus of $L$. alopecuroides through outer cortex. Confluence of basal canals is easily seen. $\times 10.27$. Median longisection of immature strobilus of L. prostratum. $\times 10$. $B C$, basal canal; $V C$, veinal canal; $S T$, sporophyll trace; $S$, sporangium. 
TABLE 1. Mucilage canal distribution ${ }^{\mathrm{n}}$

\begin{tabular}{|c|c|c|c|c|}
\hline & \multicolumn{2}{|c|}{ Canal type } & \multirow[b]{2}{*}{ Basal } & \multirow[b]{2}{*}{ Data source } \\
\hline & Absent & $\begin{array}{c}\text { Basal } \\
\text { and } \\
\text { veinal }\end{array}$ & & \\
\hline L. cruentum & $\mathrm{x}$ & & & \\
\hline L. dalhousieanum & $\mathrm{x}$ & & & Jones, 1905; Sykes, 1908 \\
\hline L. dichotomum & $\mathrm{x}$ & & & Sykes, 1908 \\
\hline L. fontanalis & $\mathrm{x}$ & & & Sykes, 1908 \\
\hline L. Iucidulum & $\mathrm{x}$ & & & \\
\hline L. nummularifolium & $\mathrm{x}$ & & & Jones, 1905; Sykes, 1908 \\
\hline L. pithyoides & $\mathrm{x}$ & & & \\
\hline L. phlegmaria & $\mathrm{x}$ & & & Jones, 1905; Sykes, 1908 \\
\hline L. quadrangulare & $\mathrm{x}$ & & & Sykes, 1908 \\
\hline L. reflexum & $\mathrm{x}$ & & & Jones, 1905 \\
\hline L. selago & $\mathrm{x}$ & & & Jones, 1905 \\
\hline L. serratum & $\mathrm{x}$ & & & Jones, 1905 \\
\hline L. squarrosum & $\mathrm{x}$ & & & Bhambie, 1965 \\
\hline L. tetragonum & $\mathrm{x}$ & & & Jones, 1905 \\
\hline L. volubile & $\mathrm{x}$ & & & \\
\hline L. alopecuroides & & $\mathrm{x}$ & & Chu, 1974; Eiger, 1956; Lloyd and Underwood, 1900 \\
\hline L. appressum & & $\mathrm{x}$ & & Eiger, 1956; Lloyd and Underwood, 1900 \\
\hline L. cernuum & & $\mathrm{x}$ & & Bierhorst, 1971; Chu, 1974; Hill, 1906; Smith, 1955 \\
\hline L. inundatum & & $\mathrm{x}$ & & $\begin{array}{l}\text { Chu, 1974; Glück, 1895; Hegelmaier, 1872; Lloyd and } \\
\text { Underwood, 1900; Sykes, 1908, } 1909\end{array}$ \\
\hline L. laterale & & $\mathrm{x}$ & & \\
\hline L. prostratum & & $\mathrm{x}$ & & Chu, 1974; Lloyd and Underwood, 1900 \\
\hline L. alpinum & & & $\mathrm{x}$ & Bower, 1894; Hill, 1906 \\
\hline L. annotinum & & & $\mathrm{x}$ & Hegelmaier, 1872; Hill, 1906 \\
\hline L. casuarinoides & & & $\mathrm{x}$ & \\
\hline L. carolinianum & & & $\mathrm{x}$ & Hill, 1906 \\
\hline L. clavatum & & & $\mathrm{x}$ & Bhambie, 1965; Hill, 1906 \\
\hline L. contiguum & & & $\mathrm{x}$ & \\
\hline L. dendroideum & & & $\mathrm{x}$ & \\
\hline L. deuterodensum & & & $\mathrm{x}$ & \\
\hline L. drummondii & & & $\mathrm{x}$ & \\
\hline L. fawcettii & & & $\mathrm{x}$ & \\
\hline L. flabelliforme & & & $\mathrm{x}$ & \\
\hline L. gayanum & & & $\mathrm{x}$ & \\
\hline L. jussiaei & & & $\mathrm{x}$ & \\
\hline L. meridionale & & & $\mathrm{x}$ & \\
\hline L. obscurum & & & $\mathrm{x}$ & \\
\hline L. scariosum & & & $\mathrm{x}$ & \\
\hline L. sitchense & & & $\mathrm{x}$ & \\
\hline L. tristachyum & & & $\mathrm{x}$ & \\
\hline L. venustulum & & & $\mathrm{x}$ & \\
\hline
\end{tabular}

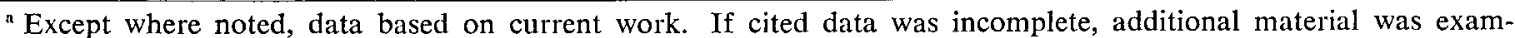
ined in order to fully assess canal distribution.

(subgenus Lepidotis) lack veinal canals in the protophylls which arise from the embryonic protocorm. If, as suggested by Bower (1885, p. 676), Phylloglossum is a "permanently embryonic form" which is related to Lepidotis, then the absence of canals in its vegetative leaves is not surprising, at least on morphological grounds. The absence of canals in the sporophylls is more difficult to explain. Reduction seems an obvious, but as yet unsupported speculation. 


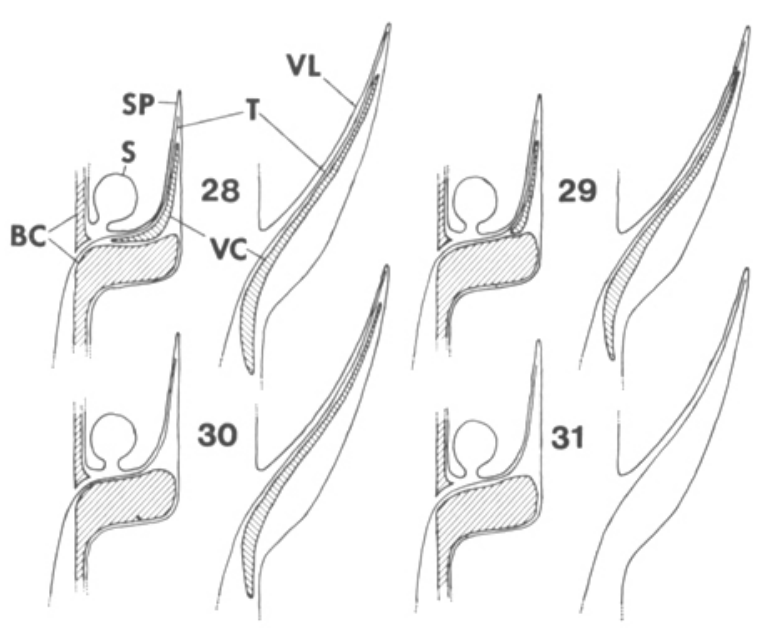

Fig. 28-31. Mucilage canal arrangement.-Fig. 2830. Subgenus Lepidotis. 28. Typical condition when both canal types are present, with veinal canal fully expressed in sporophyll. 29. Condition in $L$. laterale where veinal canal is reduced in the sporophyll. 30. Condition in $L$. cernuum where veinal canal is absent from the sporophylls but still present in the vegetative leaves. 31. Subgenus Lycopodium. Veinal canals are absent in both sporophylls and vegetative leaves. $B C$, basal canal; $V C$, veinal canal; $T$, sporophyll trace or leaf trace; $S$, sporangium; $S P$, sporophyll; $V L$, vegetative leaf.

One of the functions of the canals may be to reflex the sporophylls as the mucilage dries out during aging, thus facilitating spore dispersal (Sykes, 1908; Bierhorst, 1971). This does not, however, account for their presence in the vegetative leaves. Gluick (1895) postulated that in $L$. inundatum the mucilage, as a hydrophillic substance, retards desiccation in both the vegetative leaves and sporophylls. While this may be possible, it overlooks the fact that these plants inhabit sites that are continuously wet and humid during the growing season, such as bogs and seepage slopes. Hill (1906) speculated that the mucilage prevented desiccation in the developing strobili of such species as $L$. alpinum, $L$. annotinum, and L. clavatum. Because these taxa can inhabit drier sites than $L$. inundatum, this hypothesis may deserve greater consideration. Another possibility is that the canals may serve to localize secondary compounds, such as alkaloids for which the genus Lycopodium is well known.

The development of the canals is basically lysigenous. The growth processes are dissolution first of the cell walls and later of the protruding secretory cells which form following the loss of the cell walls. Hegelmaier (1872) contended that developing canals form in a schizogenous fashion through separation of the protruding cells from each other as the leaf expands. The mucilage, according to Hegelmaier, is then derived from a dissolution of the outer wall layers of these pro-

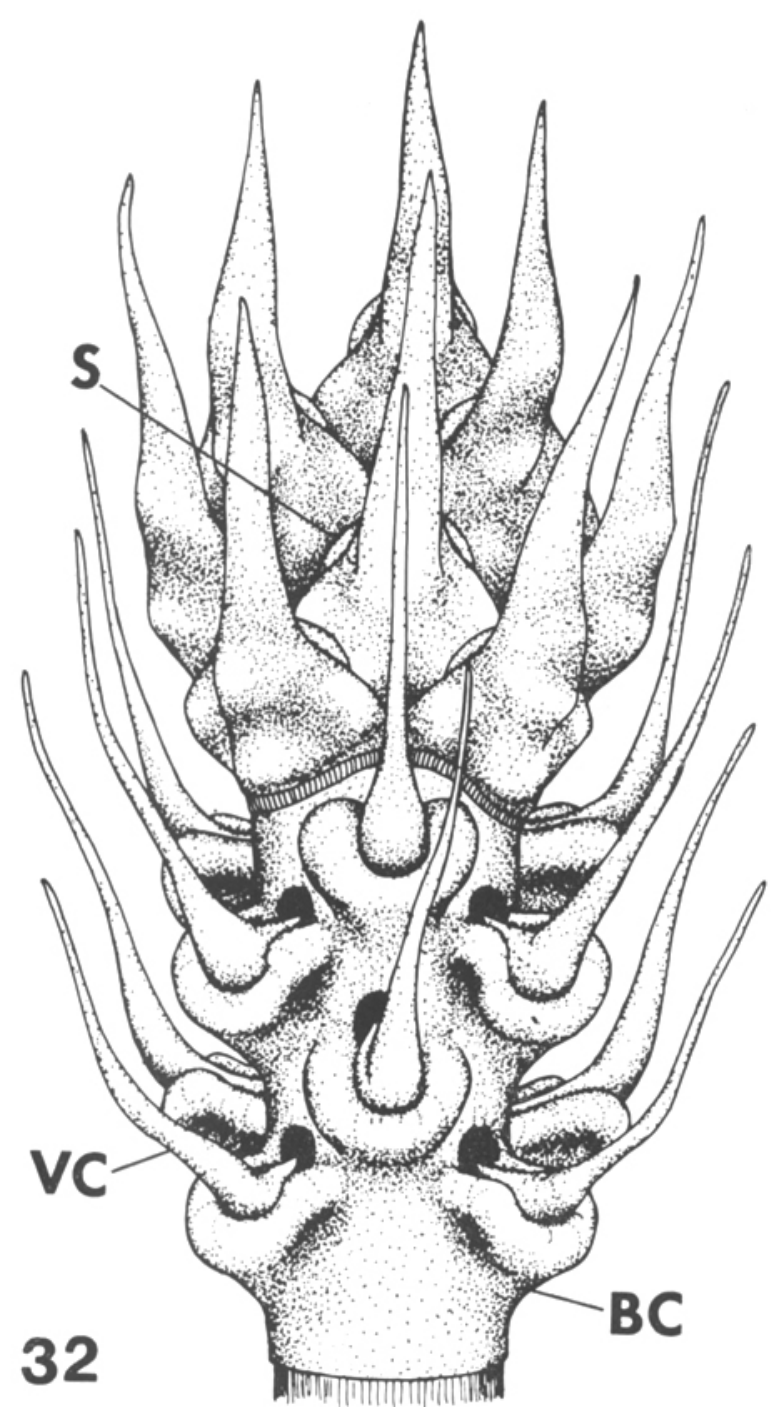

Fig. 32. Reconstruction of mucilage canals in strobilus of typical subgenus Lepidotis. Sporophylls are illustrated intact in upper part. Canals in lower portion are seen without clothing sporophyll tissues. Basal and veinal canals are shown in mature state. $\mathrm{BC}$, basal canal; VC, veinal canal; S, sporangium.

truding cells. The canal itself is the space produced by the separation of cells. Hegelmaier did suggest, however, that lysigeny may play a role because he observed infrequently a resorption of several cell layers at the position of the canal's origin. Although Hill (1906) observed lysigenous degeneration in the sporophylls of $L$. clavatum, he apparently overlooked the protruding cells entirely. In addition, he failed to realize the vertical and lateral interconnections of the basal canals as they mature, thereby forming a mucilaginous cylinder within the strobilus.

Table 1 summarizes the taxonomic distribution 
of the two types of canals. The distribution data correlate well with the classification scheme proposed by Wilce (1972) for three major subgenera within the genus. Thus, it is seen that species possessing both veinal and basal canals belong to subgenus Lepidotis. Those species possessing only basal canals are restricted to subgenus Lycopodium, while those taxa lacking canals entirely belong to subgenus Urostachys. Efforts to split the genus Lycopodium into various genera have often focused on separating the genus Diphasium which would include predominantly flat-branched taxa such as $L$. jussiaei and $L$. flabelliforme. There is no support for this concept in the distribution of mucilage canals.

Previously, Sykes (1908) reported the occurrence of mucilage canals in subgenus Urostachys in the species $L$. lucidulum, $L$. selago, $L$. serratum, L. squarrosum, and L. tetragonum. Sykes produced no photographs and her drawings were apparently meant as diagrammatic illustrations. It is, therefore, difficult to determine what she interpreted as mucilage canals. Investigation of all five of these species either in the course of the present work or by Jones (1905) or Bhambie (1965) showed no evidence of mucilage canals. In two of these cases, L. lucidulum and $L$. selago, there are, instead, schizogenous air spaces in the approximate position of a basal canal. (There is an excellent illustration of this in Foster and Gifford, 1974, p. 143). My hand sections of living material of these two species showed conclusively that these structures are air cavities which extend from within the cortex of the stem out into the leaf. Transections of a developing stem tip show that these cavities form as the leaf reflexes during its final stages of maturation. This internal splitting is apparently a consequence of the leaf moving from a position parallel, to one essentially at right angles to the stem axis. In view of these findings, it is assumed that Sykes misinterpreted the presence of mucilage canals in these species.

The taxonomic distribution of canals clearly demonstrates a trend from those species with a maximum development of both basal and veinal canals to those with only basal canals. Figure 28 illustrates typical arrangement of the two canal types in both sporophylls and vegetative leaves as seen in $L$. alopecuroides, $L$. appressum, $L$. inundatum, and $L$. prostratum. In the sporophyll of L. laterale (Fig. 29), however, the veinal canal is somewhat reduced, while in that of $L$. cernuum (Fig. 30) the veinal canal is absent, although still well-developed in the vegetative leaves. Hill (1906) stated that mucilage canals are often absent from the vegetative leaves of $L$. cernuum. There may be variation of this character in the latter species because there are numerous varieties and forms of this pantropical taxon. The ultimate stage is in the subgenus Lycopodium (Fig. 31 ) where no veinal canals at all are produced.
The foregoing sequence suggests a course of evolution in which gradual reduction and loss of the veinal canal in sporophylls was followed by loss in the vegetative leaves. This seems to go hand-in-hand with the gradual specialization of the sporophylls from subgenus Lepidotis where they are often fleshy and leaf-like, as in $L$. alopecuroides, to subgenus Lycopodium where they are hard and specialized in form. The distribution of the canals, therefore, suggests that subgenus $L y$ copodium may have been derived from elements within subgenus Lepidotis.

Lycopodium carolinianum has been placed by various authors in subgenus Lepidotis (genus Lycopodiella) (Wilce, 1972; Pichi Sermolli, 1968) although, on the basis of the new data presented here, the distribution of its mucilage canals suggests alignment with subgenus Lycopodium. A number of features of this plant are more or less anomalous with respect to typical members of subgenus Lepidotis (Bruce, 1974).

The apparent absence of mucilage canals in $L$. volubile suggests placement in subgenus Urostachys. However, the spores of this species, although unusual (Wilce, 1972), certainly seem to fit within the variation shown for subgenus $L y$ copodium. Lycopodium volubile has an unusual arrangement of its sporophytic reproductive structures. The peduncle is branched as in many members of subgenus Lycopodium, but the strobili are also branched giving the appearance of the tasseled members of subgenus Urostachys with forking, pendant fertile axes (Holloway, 1919). The sporophylls themselves do not possess the peltate character (Boivin, 1950) found in subgenus Lepidotis or in subgenus Lycopodium, but resemble the broad based sporophylls of subgenus Urostachys. It should be pointed out that the peltate condition is correlated with the presence of basal canals in the sporophyll, and it is most prominent in dried material when the basal canal becomes quite contracted. Thus, a basal canal and a peltate sporophyll are probably different expressions of the same character. Also, as in subgenus Urostachys, the sporangial stalk is both narrow and axillary, as opposed to being thick and on the sporophyll, as in subgenus Lycopodium. However, the gametophyte (as described by Edgerley, 1915) is similar to those described for subgenus Lycopodium in that, among other features, it is subterranean in habit and lacks the small multicellular paraphyses found in subgenus Urostachys (Rothmaler, 1944, 1954). There are a number of features of this taxon which need further study before its relationships are settled.

\section{LITERATURE CITED}

Bhambie, S. 1965. Studies in pteridophytes. V. The development, structure and arrangement of leaves in some species of Lycopodium. Proc. Ind. Acad. Sci. 61: 242-252. 
Bierhorst, D. W. 1971. Morphology of vascular plants. Macmillan Co., New York.

Bolvin, B. 1950. The problem of generic segregates in the form-genus Lycopodium. Amer. Fern J. 40: $32-41$.

BOWER, F. O. 1885. On the development and morphology of Phylloglossum drummondii. Philos. Trans. 176: 665-678.

-2. 1894. Studies in the morphology of sporeproducing members.--Equisetineae and Lycopodineae. Philos. Trans., Ser. B 185: 473-572.

BreckoN, G. J., aND R. H. FALK. 1974. External spore morphology and taxonomic affinities of $P h y l$ loglossum drummondii Kunze (Lycopodiaceae). Amer. J. Bot. 61: 481-485.

BruCE, J. G. 1974. Observations on the relationships of Lycopodium carolinianum. Amer. J. Bot. 61 (5, supp.): 35. (Abstr.)

CHu, M. C.-Y. 1974. A comparative study of the foliar anatomy of Lycopodium species. Amer. J. Bot. 61: 681-692.

Edgerley, K. V. 1915. The prothallia of three New Zealand lycopods. Trans. New Zealand Inst. 47: 94-111.

EIger, J. V. 1956. A hybrid Lycopodium. Biol. Rev., C. C. N. Y. 18: 17-22.

Foster, A. S., ANd E. M. Gifford, Jr. 1974. Comparative morphology of vascular plants. 2nd ed. W. H. Freeman and Co., San Francisco.

GLück, H. 1895. Die Sporophyllmetamorphose. Flora 80: 303-387.

Hegelmaier, F. 1872. Zur Morphologie der Gattung Lycopodium. Bot. Zeit. 30: 773-779, 789-801, $805-819,825-834,837-850$.

HiLl, T. G. 1906. On the presence of a parichnos in recent plants. Ann. Bot. 20: 267-273.

Holloway, J. E. 1919. Studies in the New Zealand species of the genus Lycopodium: Part III-The plasticity of the species. Trans. New Zealand Inst. 51: 161-216.
C. 1935. The gametophyte of Phylloglossum drummondii. Ann. Bot. 49: 513-519.

JohnNSEN, D. A. 1940. Plant microtechnique. McGraw-Hill Book Co., New York.

JoNES, C. E. 1905. The morphology and anatomy of the stem of the genus Lycopodium. Trans. Linn. Soc. London, Bot. 7: 15-35.

Lloyd, F. E., AND L. M. Underwood. 1900. A review of the species of Lycopodium of North America. Bull. Torrey Bot. Club 27: 147-168.

Pichi Sermolli, R. E. G. 1968. Fragmenta pteridologiae-I. Webbia 23: 159-207.

Rothmaler, W. 1944. Pteridophyten-Studien I. Feddes Repert. Spec. Nov. Regni Veg. 54: 55-82. - 1954. La taxinomie des Lycopodiales. Huitième Congrés Internationale de Botanique 1954, p. $18-19$.

SAMPSON, K. 1916. The morphology of Phylloglossum drummondii, Kunze. Ann. Bot. 30: 315-331.

SASs, J. E. 1958. Botanical microtechnique, $3 \mathrm{rd}$ ed. Iowa State Univ. Press, Ames.

ScHmID, R. 1971. Floral anatomy of Eugenia sensu lato (Myrtaceae). Ph.D. Thesis, The University of Michigan.

Sharman, B. C. 1943. Tannic acid and iron alum with safranin and orange $G$ in studies of the shoot apex. Stain Technol. 18: 105-111.

Smith, G. M. 1955. Cryptogamic botany, Vol. II. 2nd ed. McGraw-Hill Book Co., New York.

Sykes, M. G. 1908. Notes on the morphology of the sporangium-bearing organs of the Lycopodiaceae. New Phytol, 7: 41-60. 1909. Note on the sporophyll of Lycopodium intudatum.-A correction. New Phytol. 8: $143-$ 145.

Treub, M. 1890. Études sur les Lycopodiacées. VI L'embryon et la plantule du Lycopodium cernuum L. Ann. Jard. Bot. Buitenzorg 8: 1-15.

WiLcE, J. H. 1972. Lycopod spores, I. General spore patterns and the generic segregates of Lycopodium. Amer. Fern J. 62: 65-79. 